Made available courtesy of Human Kinetics: http://www.humankinetics.com

***Reprinted with permission. No further reproduction is authorized without written permission from the Human Kinetics.

This version of the document is not the version of record.

Figures and/or pictures may be missing from this format of the document.***

\title{
Curriculum: Forming and Reshaping the Vision of Physical Education in a High Need, Low Demand World of Schools
}

\author{
Catherine D. Ennis
}

\begin{abstract}
This paper highlights events and issues in the development of physical education as a school subject. From the origin of physical culture in the German and Swedish "Battle of the Gymnastics Systems" to the advent of the New Physical Education in 1927, physical education curriculum has been a contested terrain. This remains true today as physical educators must compete for school funding and other resources with highly valued subject areas. Unfortunately, serious contextual constraints continue to hamper the efforts of highly motivated, effective physical educators to teach physical education content in schools. Perhaps in the future, better opportunities can be found in other venues where physical education can one day be perceived as a high need, high demand priority for children and their families.
\end{abstract}

At the time the American Academy of Physical Education (AAPE) was founded in 1930, the current subdiscipline of pedagogy was described almost exclusively as physical education. Today, research and scholarship in physical education pedagogy are best understood as a deep integration of curriculum, teaching, and teacher education. In 1930, however, physical educators were engaged in an intense debate primarily associated with the classic curriculum question: "What physical education content is of most worth or value for children?" (e.g., Broudy, 1982). Today, these issues and concerns continue to shape our understanding of physical education in school programs. For this paper, I will focus primarily on the development of physical education as a school subject. Specifically, I will discuss how the vision of school-based physical education has been formed and shaped within the high need, low demand world of schools. In this process I will divide the paper into three sections: Historical Roots, the "New Physical Education," and the current High Need, Low Demand Dilemma.

The author (AAKPE Fellow \#381) is with the Department of Kinesiology at the University of Maryland in College Park, MD 20742-2611. E-mail: cde@umd.edu. 


\section{Historical Roots}

By the time Clark Hetherington (1922), Luther Gulick (1920), Tait McKenzie (1923), and Mabel Lee (1937) shifted their attention to the formation of the American Academy of Physical Education in the late 1920s, school based physical education was developing along three major themes: health and hygiene, recreation, and education. Physical education curriculum in the United States developed as a contested philosophical terrain (e.g., Sage, 2003) with diverse principled positions, leading to a variety of curricula that can be seen in community and school programs today (Bair, 1957; Capel \& Piotrowski, 2000; Vertinsky, 1991).

Physical exercise or culture first made a sporadic appearance in schools in the early 19th century. Leonard (1927) described systems of physical training in the United States in the mid-1800s: Jahn gymnastics system, which gradually evolved into programs of military-type drill and discipline and the Swedish movement cure, sometimes described as the Swedish system of gymnastics. German immigrants brought Jahn social gymnastics clubs, called Turnverein, to the United States in the 1820s. The Turnverein style of gymnastics, observed at Harvard College in the 1830s, was described as an amazing sight: "young men [were] climbing, swinging, and twirling aloft in the open playground" (Leonard, 1927, p. 240).

Following the Civil War, the German gymnastics style took on a more of a military drill format, emphasizing mental and physical discipline. Men challenged themselves to redevelop the "toughness" and physical health many had lost as they moved from farm work to more sedentary occupations in urban areas. In 1866, John Swett, Superintendent of the California Board of Education, successfully included the first formal course in physical education as a requirement in California schools (Hoepner, 1970). Swett had reinvigorated his health through hard work in the gold fields of California in the 1850s and had become a strong supporter of the German Turnverein approach to gymnastics.

The German gymnastics system's emphasis on physical and mental discipline continued to attract men and boys to the program well into the early 1900s. In 1921, Skarstrom, a proponent of German gymnastics exercise, explained that the system included activities that involved muscular contraction, coordination, mental effort, fatigue, and a strict focus on physical and mental discipline. Content divisions in Skarstom's approach to "kinesiological gymnastics" emphasized "marching, free standing exercises (with and without hand apparatus), apparatus work, and class running and running games" (Skarstrom, 1921, p. 92). Some activities, said to include jumping on one's toes, gradually evolved into dance steps.

In the 1850s, Per Henrik Ling developed the Swedish Movement Cure, a system of gymnastics exercises that emphasized the therapeutic value of movement (Leonard, 1927). In the late 1880s, Hartvig Nissin, a Norwegian, began teaching a modified version of the Swedish system to boys and girls at the Franklin School in Washington, DC in 1883, young men and women at Johns Hopkins University in 1887 , and to children in the Boston public schools after its adoption by the School Board in 1890. Swedish or medical gymnastics used exercises and apparatus to promote health and hygiene for participants (Leonard, 1927). Thus, the Swedish gymnastics system's emphasis on medically-related movement added a new and quite different perspective when compared with the discipline-oriented focus of the German system. 
German and Swedish systems of gymnastics continued to compete for prominence following the Civil War and began to appear more routinely in schools during the 1880 s. So strongly did advocates argue the case for these alternative approaches to gymnastics that their debates were described as the "Battle of the Systems" (Weston, 1962). This was the first of many curricular controversies to plague the development of the physical education subject area in school programs over the next century.

This very vigorous approach to physical exercise emphasized the "education of the physical" perspective that presaged other forms of fitness-oriented curricula. Halsey (1964), however, pointed out that the gymnastic content emphasis on obedience and discipline was not as popular with girls as with boys who sought passage into manhood through the tough physical routines. Following young male draftees' generally poor physical performance on fitness tests in 1917, the gymnastic systems approaches in schools "began to decline as trainers found that children would work hard toward their own interests, but put out much less real effort in some activity outside [their] understanding" (Halsey, 1964, p.15).

Prior to World War I, significant cracks in the gymnastic systems occurred both from within, as a product of the continuing Systems debates and from without, as progressive educators sought a more enjoyable, recreational approach to physical activity. Similar to colleagues in other subject areas, physical educators embraced the innovative perspectives proposed by John Dewey (e.g., 1899, 1916) as an opportunity to provide a more enriching atmosphere and a diversified curriculum (Hanmer, 1918, p. ix). Dewey (1916) argued persuasively that curriculum should reflect the larger life outside school and should be organized to represent the current and evolving community, not reproducing current habits but teaching new ones.

Schools, as a result of the Elementary and Secondary School Act of 1918, now were charged with the physical, mental, and social training of the child. Advocates sought to make school and physical education a place where children lived as well as learned. Spurred by the progressive writing of John Dewey, founders of the American Academy of Physical Education developed a new approach to physical education that refuted the traditional gymnastics systems. In 1927, they proposed an innovative, modern approach that embraced diverse goals and content within a formal approach to curriculum. This program, articulated in a text by Thomas D. Wood and Rosalind Cassidy (1927), was entitled the New Physical Education: A Program of Naturalized Activities for Education Toward Citizenship.

\section{The New Physical Education}

The New Physical Education was conceptualized in the early 1900s by physicians, Clark W. Hetherington (1922), Luther H. Gulick (1920), R. Tait McKenzie (1923), and Thomas D. Wood (1924) as a modern philosophy of physical education (Weston, 1962). Breaking from the rigid gymnastic systems approach, Hetherington proposed that physical education should contribute to the total education of the child. He emphasized that a program of physical education must be rooted in American society and constructed to train children for democratic citizenship. He argued that such training was impossible in the current German and Swedish gymnastics systems because of their origin in different cultures with markedly different values. 
Luther H. Gulick (1920) contributed to the development of this perspective by designing programs in physical education, recreation, and camping that emphasized the social value of physical education. He promoted the New Physical Education in programs designed for community organizations and youth groups that encouraged "healthy relaxation and recreation free from the tensions of a highly industrialized" society (Weston, 1962, p. 52). Hetherington and Gulick believed that physical education "possessed inherent educational values capable of transforming the mental, physical, emotional, and social qualities of an individual to approach more closely the ideal of the educated man" (Weston, 1962, p. 52).

\section{Educating the Total Child}

Students of Hetherington, Gulick, and Wood, such as Jesse Feiring Williams (1922), Jay B. Nash (1931), and Rosalind Cassidy (Brown \& Cassidy, 1963; Cassidy, 1954; Cassidy \& Kozman, 1943; Wood \& Cassidy, 1927), shaped the philosophical foundations of the New Physical Education in a manner consistent with the educational, sociological, and psychological objectives advocated by John Dewey (i.e.,1908, 1913, 1916), Edward L. Thorndike (1913), and G. Stanley Hall (1920). Specifically, Williams and Nash argued that the New Physical Education focused on educating the complete human being through an emphasis on mind and body. Rather than a program of mindless exercise, the New Physical Education proposed students be educated "through the physical" (Williams, 1930) such that the mind, emotions, and human body formed a complete action (Weston, 1962).

According to Williams, The New Physical Education programs should be academically sound and meet age, needs, and interests of those involved. Contrary to the discipline-oriented gymnastics systems, the goal of this new approach to physical education was "to teach physiologically sound movement patterns, building them into avenues of expression essential in performing activities at home, in professions and vocations, and in leisure time activities" (Weston, 1962, p. 72). Curricular content choices within the New Physical Education included sports and games, rhythmic activities, and selected gymnastics progressions based on educational objectives.

During the early 1900s, physical educators, following the work of Gulick and Hall, proposed that the activity forms of games, dance, and sport were natural extensions of play and, therefore, fundamental to the development of the child. These forms of activity were thought to integrate mind and body and give play meaning to children and to the society as a whole. Thus, play became a valuable educational experience rather than an activity in and of itself. This extension of the goals of the New Physical Education beyond the development of the physical body to the education of the mind through physical activity was a natural step following the development of physical education within the academic school environment (Mechikoff \& Estes, 1998).

\section{Philosophical Basis of the New Physical Education}

By the 1930s, when the American Academy of Physical Education was forming, the New Physical Education was providing programs focused on competitive 
sports for boys and a broad array of physical activities for girls, including rhythmic activities, dance, and a less competitive form of sports and games than that taught in the boys' physical education curriculum. Thomas D. Wood and Rosalind Cassidy (1927) described the New Physical Education as a "natural program . . . with its center in America and significant beginning in the Department of Physical Education at Teachers College, Columbia University" (p. vii). In 1927, Wood and Cassidy reported that the New Physical Education now "had 15 years of earnest, devoted, scientific research in the formulation, application, and testing of theory and practice" (p. vii). They identified two purposes:

First, to provide the scientific basis of a naturalized program of activity that is truly educational, and, therefore, the logical and necessary program for children in this American democracy; second to answer the demand for definite printed facts on the history, scientific basis, aims, content, and method of a natural program. (p. viii)

They explained that physical education activities must be grounded in the original nature of the human being and provide satisfying expression in vigorous action for the wholesome, natural instincts and impulses of children and youth (p.vii). Further,

... a program of physical education which is scientifically, socially, and educationally sound must not only make generous provision for satisfying expression of natural demands and impulses for action, but must also give recognition and adequate place to modifications, adaptations, and additions, in response to racial, national, community, vocational, avocational, and individual needs in our present civilization. (p. viii)

The New Physical Education described by Wood and Cassidy (1927) included an emphasis on biology, physiology, and sociology and the importance of matching the physical, mental, social, and emotional needs of the developing child to the content. The text described lesson plans and student-designed projects as a way to engage students in the learning process. Further, it included very explicit measurement scales for growth, knowledge, skills, and attitudes and proposed a "Learner's Method of Study" that explained strategies to teach children to learn by doing "with complete motor training grounded in concrete goals of activity" (Wood \& Cassidy, 1927, p. 4). Of particular interest in this academically-oriented curriculum were strategies to adapt the material for classroom use, an articulation of the role of the teacher and supervisor in promoting effective teaching, and a check list of questions to assess quality teaching. Although physical education programs were taught separately for boys and girls after age 12, the authors assumed that the same content and presentation were appropriate for both. This prototype for the New Physical Education was a marked departure from the earlier gymnastics system approaches and was influential in shaping perceptions of teachers and teacher educators over the next 80 years.

Thus, the contested terrain of school-based curriculum during the early decades of the 20th century was easily as contentious as the curriculum discussions of more recent times. In fact, advocates of the New Physical Education offered a novel approach to physical activity for individuals of that era and perceived that 
physical activity possessed inherent value for both recreation and health. Further, trained physical education teachers were needed to assist students to become more skillful in a diverse array of physical activities from the primary grades through the university level. This need gave rise to teacher education programs with the goal of broadening teacher knowledge of physical activity forms and the ability to enhance and assess physical performances (Wood \& Cassidy, 1927).

\section{Evolution of the New Physical Education: 1930-1960}

Between World War I and World War II, Spears and Swanson (1978) explained that sport, exercise, dance, and physical activity were integral parts of the educational system in the United States. Programs for men and women were distinctly different, with men's programs focusing on competitive sport, while women's programs continued to reflect a variety of activities, including sport and games, gymnastics, body mechanics, and dance.

The quality of physical education programs began to be examined in the 1930s using the LaPorte $(1931,1932)$ Physical Education Score Card. The LaPorte Score Card, while providing a range of scores for physical education programs, made little note of the nature of the content or criteria for acceptable physical performances in these programs. In fact, of six assessment categories, only one focused on content, while the remainder assessed the quality of the administration and facilities. The LaPorte Score Card continued to be used well into the 1960s and contributed to researchers' evaluations of programs based on an assessment of factors other than teaching and student learning. Much of this research, assessing differences in fitness levels of boys involved in good versus poor physical education programs (e.g., Rosenstein \& Frost, 1964; Saunders, Montoye, Cunningham, \& Kozar, 1969), conceptualized physical education as a monolithic structure, assuming that all physical education programs for boys were structured similarly around a core set of competitive sport activities. An exception to this pattern was found in research conducted by Franks and Moore (1969). These scholars described the physical education content of programs they evaluated and attributed differences in fitness test performance to characteristics of content rather than more tangential factors surrounding the program.

In 1943, Rosalind Cassidy again proposed a cutting edge curricular innovation for girls' physical education. With co-author, Hilda Kozman, she conceptualized a diversified, educational approach to personal fitness, specifically designed to appeal to girls. The text, Physical Fitness for Girls, rejected militaristic, or "fitness for war" approaches that some were proposing for young girls. In the preface to this text, Lindeman (1943) condemned "exercises prescribed for young college girls which are direct imitations of the training now being offered to so-called commandos" ( $p$. v). In this text, Cassidy and Kozman proposed a concept of "wholistic" physical fitness in which "the body [is] an efficient instrument of the self for meeting life situations" (1943, p. 32). They described physical fitness for girls as having elements of endurance, strength, body control, relaxation, and morale (i.e., motivation and purposefulness to achieve fitness).

The concept of the New Physical Education continued to be developed and expanded through the 1950s by students of Thomas D. Wood, such as Rosalind 
Cassidy (1954) and Delbert Oberteuffer (1951). Both championed physical education based on a democratic approach to education derived from the philosophical perspectives originating in the New Physical Education. These programs traced their foundations to the biological and physiological science advances of the day, demonstrating consistency with current knowledge in human and motor development and grounded in theories of social relationships. While Cassidy continued to develop and apply progressive strategies in physical education in the form of student-designed project-based approaches proposed by Dewey (1916) and Kirkpatrick (1922), Oberteuffer (1951) stressed the importance of the acquisition of motor skills based on scientific principles of motor learning. Clearly, both scholars emphasized the value of learning physical skills and strengthening the body (education of the physical) within a broader perspective of social and personal development (through the physical) with "physical education as a medium of education" (Oberteuffer, 1951, p. vii.)

Following World War II, physical educators again asked whether the competitive sport emphasis that dominated men's programs between the World Wars was the best means to produce physical fitness (Halsey, 1964). As a response to this criticism, male physical educators revived an interest in military drill-oriented gymnastics and coaches became "very tough about toughness" (Halsey, 1964, p. 22). Further, data from the Kraus-Weber Test of Minimum Strength (Kraus \& Hirschland, 1954), a measure of minimal functioning of the low back area, indicated that United States children were weaker than their European (i.e., Italian and Austrian) counterparts. The media, in particular US News and World Report (1954), carried the story, reporting that "such weaknesses set up the conditions that lead to other physical trouble, and in all likelihood, mental trouble, too" (p. 36). Federal and state government agencies appointed committees and councils to study and promote physical fitness, leading to a surge in the development of new instruments to measure and study fitness levels. This national media interest stimulated the development of the President's Council on Physical Fitness and Sport and the AAHPER conference on Youth Fitness, both in 1956. By 1960, the American Medical Association had passed a resolution to support physical education and health, encourage effective instruction in physical education, and support sports and games as important leisure time skills to relieve tension and help alleviate effects of a sedentary life. President John F. Kennedy, in December, 1960, weighed in on the concerns of an unfit nation in a Sports Illustrated article titled, "Soft American." Physical education continued to be the focus of philosophical tensions between sport and fitness advocates into the early 21 st century.

\section{A Question of Relative Value}

The revival of interest in fitness in the 1950s came at a time when schools were facing a different set of external pressures. Following the Soviet Union's launch of Sputnik in 1957, politicians criticized school curricula as weak in science and mathematics and declared this the primary reason the United States had lost the "space race" to the Soviet Union. Thus, schools faced unprecedented pressure to increase students' academic abilities, and educators and scholars embarked on a rigorous revitalization of mathematics and science content. Although the KrausWeber fitness data created a curricular impetus toward intensified personal fitness 
content, competition was fierce as school administrators searched for additional instructional time to devote to the disciplines of mathematics and science. School subjects, including physical education, in an effort to maintain and promote a rationale for their continued existence, began a process of self-legitimization, creating taxonomies of essential knowledge to reestablish and solidify their place in the school curriculum.

Although during the second half of the 20th century school administrators acknowledged the benefits of fitness and physical health, the relative low value of physical fitness and physical education compared to the academic disciplines left physical education scholars feeling marginalized and defensive. Beginning with Franklin Henry's classic speech in 1964, scholars in the American Academy of Physical Education debated periodically for two decades whether the content of physical education could be labeled a discipline. Those with ties to schoolbased physical education advocated for the designation of physical education as a professional or clinical discipline, while scholars in exercise physiology, motor development, learning and control, sociology, and psychology pursued opportunities to connect and engage with scholars in their parent disciplines (Fraleigh, 1979; Zeigler, 1979). Although this was an era of concern for "disciplinary unifiers," the departure of scholars within the "subdisciplines" left pedagogically-oriented physical educators alone to shape and focus the research agenda in physical education teaching, teacher education, and curriculum.

\section{Theoretically Based Approaches to Physical Education Curriculum}

Throughout the 1960s and 1970s, curriculum scholars and content area specialists in most subject areas used taxonomies and content outlines to articulate their theoretical knowledge base, defining and elaborating essential components of their content. They devised theoretically-based curricular designs, proposing that content be organized around thematic concepts rather than isolated activities. In physical education, Camille Brown and Rosalind Cassidy's (1963) text, Theory in Physical Education: A Guide to Program Change, reflected this perspective. Brown and Cassidy defined theory as "a systematic statement of facts and principles and the formulation of apparent relationships which have been verified to some degree" (p. 19). They argued that according to Beauchamp (1975), "a theory is only useful if it can be tested in practice, modified in practice, or accepted in practice" (p. 11).

Brown and Cassidy proposed a comprehensive definition and taxonomy of knowledge that constituted the field of physical education. They explained that this was "essential to develop more clearly the role of human movement in the individual's growth and development and the individual's needs in today's and tomorrow's world and outer-world" (Brown \& Cassidy, 1963, p. 7). In this text, they defined physical education as "the art and science of human movement" a definition we think of today as consistent with our understanding of the term, kinesiology (p. 8). Brown and Cassidy described the change toward the development of the discipline of physical education as the second major physical education programmatic evolution following the "New Physical Education" in the 1920s.

Ann E. Jewett was instrumental in conceptualizing taxonomic structures of content and furthering the perspective that physical education content was 
legitimated based on its personal meaning and relevance to the individual performer or participant. In a paper presented to the American Academy of Physical Education in 1968, she reiterated the call for development of a physical education theoretical base (Jewett, 1968). She argued that curriculum theory was sorely lacking in physical education, leading to an inability to conceptualize and sequence content for learning.

Between 1965 and 1970, the American Association for Health, Physical Education, and Recreation (AAHPER) sponsored the Design Conference on Physical Education as an Area of Scholarly Study and Research, the Conference on the Physical Education Theoretical Structure Project, and three regional conferences to provide opportunities for further discussion of the theoretical structure of physical education. The focus of these conferences was the identification of the theoretical structure of physical education knowledge to assist scholars, researchers, and practitioners to understand topics that should and should not be included in physical education. The work of these conferences was published in an AAHPER sponsored pamphlet entitled, Tones of Theory (Ulrich \& Nixon, 1972). The conference participants concluded that the conceptual theory of physical education included "affective and cognitive substance as well as activity patterns, play with a purpose rather than having fun, and a holistic rather than atomistic commitments to the study of man" (p. 25). Topics and movement forms that were excluded from the physical education program were athletics, health, safety, recreation, and outdoor education (Ulrich \& Nixon, 1972).

Jewett reiterated the importance of developing a conceptual framework for physical education in speeches to the Academy in 1973 and 1974. In these speeches, she provided guidance in developing theoretically based physical education curriculum, proposing the use of thematic concepts or purposes for human movement as essential to the theoretical structure of the discipline. Jewett continued her leadership in curriculum theory by publishing a model based on assumptions of personal meaning in participant's content choices. This model, entitled the Purpose-Process Curriculum Framework (Jewett \& Mullan, 1977) was based on a conceptually sophisticated theoretical framework that organized and nested content concepts to facilitate curriculum development. Personal meaning was the theme of the AAPE program in 1975 and continues today as a salient theme in physical education curriculum theory and design.

Jewett's emphasis on the conceptualization of coherent, theoretically-based curriculum models chronologically paralleled the educational use of the Movement Framework(s) developed independently by Rudolph Laban and Margaret H'Doubler as the conceptual framework for a new model of Movement Education (e.g., Logsdon et al., 1967; Mauldon \& Redfern, 1969). This model continues to provide a theoretically coherent approach to children's movement currently implemented in some elementary physical education programs (e.g., Graham, Holt/Hale, \& Parker, 2004).

Other scholars responded to the need for conceptually coherent approaches to content by designing curriculum organized around essential concepts. Of particular note was the work of Charles Corbin and his colleagues (Corbin, Dowell, Lindsey, $\&$ Tolson, 1970) who developed a personal fitness knowledge framework organized around five fitness components that provided a coherent organizing structure for this content. 
More recently, pedagogists have proposed a new generation of curriculum models that trace their historical origins to the New Physical Education. Goals and assumptions of these models continue the emphasis on addressing individual needs, interests, and abilities of participants within sport (Siedentop, Hastie, \& van der Mars, 2004), games (Mitchell, Oslin, \& Griffin, 2005), and fitness (Corbin \& Lindsey, 2005). Likewise, the themes of individual and social responsibility also resonate in the contemporary approaches to community-based programs proposed by Hellison and his colleagues (Hellison et al., 2000).

Social critical scholars and pedagogists advocate the use of physical education to assist students in examining the subtle and salient influence of media and cultural messages to better understand the impact of marketing on their conceptualization of the gendered body (e.g., Kirk, 1988; Penney \& Evans, 1999). Azzarito and Solmon (2005), for example, argued that declines in youth participation in physical activity can be traced to problems inherent in traditional, multiactivity, sport-based approaches to physical education. Physical education curriculum, in which students take an active role in the construction and analysis of the dynamic relationships between gender, race, and social class, is central to the sociocritical reconceptualization of physical education. They stressed that "the field of physical education needs to open and embrace a complicated dialogue across cultures, histories, individual identities and ways of being" (p. 43).

Lee and Solmon (2005) chronicle much of this work and the related developments in teaching and teacher education in their recent article commemorating the 75th anniversary of the Research Quarterly for Exercise and Sport. Suffice it to say, the period from the 1980 s into the first decade of the 21 st century was a time of dramatic growth in which pedagogists examined and critiqued the school context and its impact on curriculum, teaching, and learning. Likewise, scholars analyzed many aspects of teacher education and professional staff development to enhance and strengthen the qualifications of pre-service and in-service teachers in physical education. Of particular note, the National Association for Sport and Physical Education (NASPE) sponsored a series of committees and professional conference sessions to forge a philosophical consensus around national standards for physical education content (NASPE, 2004) and teacher education programs (NASPE, 2003).

Curricular scholars have designed and tested a number of concept-based, thematic approaches to physical education that permit more effective content sequencing, an essential element to learning-oriented programs (e.g., Nixon, 1969). Many of these models rely on cognitive theories of learning represented by constructivist practices in which teachers provide guidance and support to students as they construct their understanding of content. In these models, both the focus on education through the physical as exemplified by the "the New Physical Education" and the emphasis on education of the physical through personal fitness and physical activity curricula are being conceptualized in increasingly more dynamic and personally relevant ways. These approaches seek to develop deeper integration or natural connections between physical education content and content in other subject areas. For example, the Be Active Kids! curriculum developed at the University of Maryland for 3rd - 5th grade children integrates physical education and science education content based on alignment with national standards in both 
content areas. This curriculum merges emphasis on physical activity with cognitive concepts as a natural extension of the New Physical Education into the 21st century (Ennis, Chen, \& Sun, 2005).

Although there is still much to learn about the development of effective physical education programs that promote the development of mind and body, there continue to be nagging problems associated with the school-based delivery of physical education that limit program effectiveness and constrain the ability of physical educators to engage and teach students within the school context.

\section{Physical Education in the High Need, Low Demand World of Schools}

Tracing the historical development of school-based physical education reveals a number of issues that provide an understanding of the challenges that physical education must overcome within the school context. Initially, physicians and physical educators looked to public schools for the opportunity to provide programs that reached most children in the United States. Although health and hygiene curricula provided the original impetus to link physical education curricula with schools, these gymnastics programs became too physical (e.g., rigorous, rough, militaristic) for educators to support and sustain within educational environments.

The advent early in the 20th century of The New Physical Education curricula signaled deep dissatisfaction with the singular purpose of educating only the physical body, ushering in a broader, more humanistic approach, mirroring educational practices of the day. Its focus on education of and through the physical avoided the false dichotomy of one perspective or the other. Further it succeeded through the work of scholars, such as Cassidy (e.g., 1954) and Oberteuffer (1951), to teach students not only how to perform but also to explain why movements were more or less effective and to examine the effects and benefits of physical exercise on bodily systems. It is important to note that teaching these complex curricula required highly trained teachers who were knowledgeable in the disciplines of physical education and could instruct students in performance. This more sophisticated approach to teaching required teachers not only to explain the kinesiological knowledge base, but also to understand pedagogical content knowledge (Shulman, 1986) necessary to teach content for learning.

The academic focus of the New Physical Education may have been instrumental in solidifying the place of physical education in public and private schools in the early and middle decades of the 20th century. The advent of the Sputnik age, however, with the increasingly narrow focus on content central to the school mission and the focus on standardized testing in core subjects, sorely constrained physical education programs. For example, in 1955, Cowell and Hazelton reported the following:

In too many schools, physical education (including athletics) is treated as a "dangling appurtenance" to the academic structure, instead of an integral part of it. While children are carefully classified and scheduled into English and Mathematics, students are often assigned to physical education whenever they 
have a free period and often in groups including two or three grade levels .... (p. 43)

This problem continues today, greatly limiting the ability of highly qualified, dedicated, and motivated physical educators to enhance student learning in schoolbased physical education. In 1970, Wallace Ann Wesley, assistant director for the American Medical Association, exclaimed in an invited reaction to an American Academy symposium that

Physical education with education should come out of the schools. They should go into high rise buildings and into neighborhoods. Couldn't we teach at a time of day that is convenient to such dwellers? Let's get physical education to the people, not just as an activity, but [to enhance] their understanding of why it's important. (p. 17)

By 1979, during the height of the disciplinary fragmentation/specialization debates, Earle Zeigler, in his address to the American Academy of Physical Education, summarized the situation:

Physical education is so important to people of all ages in our society that its future in our schools is guaranteed forever-no matter whether true professional status is acquired or not. Nevertheless, the current status of physical education is seriously ill. (p. 9)

Two years later Dorothy Harris, in her address to the Academy in 1981, summarized the problem that continues today to plague the practice of physical education in schools:

... it appears that physical education generally has failed to make a sufficient impact within, as well as outside the school system, to maintain the support and recognition necessary to be accommodated and facilitated as it should be in the educational arena. It is one of the first subjects to feel the economic squeeze in time of budgetary curtailments. In short, it appears that physical education has not convinced the public of its worth. (p. 32)

Despite the advent of the Department of Education Carol White Physical Education for Progress (PEP) grants to public school districts, the problems in 2005 appear to be becoming increasingly severe as physical educators at all levels work to enhance significantly the quality of programs plagued in many geographic areas by steadily declining resources. Although our medical and public healthoriented colleagues tell the nation that we are facing an obesity epidemic fueled by nutritional super-sizing and an increasingly more sedentary lifestyle, public school administrators and teachers are facing monumental pressures to educate a linguistically and culturally diverse student body to unprecedented standards in literacy and mathematics. Today, the hoops through which administrators and educators must jump are rimmed with fire-failure on standardized tests leads to school reconstitution and reallocation of scarce resources to other academically more successful schools.

Although I would be among the first to tout the value of literacy and mathematics, the enormous price borne by other subject areas is monumental. In the 
elementary school, for example, the Maryland State Department of Education (2004) requires uninterrupted blocks of 150 minutes of reading and 120 minutes of mathematics every day for primary level students. This allocation of four and a half hours of a six-hour elementary school day forces other subjects to sideline positions. Even central core subjects such as social studies and science education may be scheduled into the elementary curriculum once weekly for a 30-minute period.

In Maryland, physical education continues to be somewhat protected from elimination by a state law that currently requires it to be taught as one of seven mandatory subject areas. However, within the last four years, the number of instructional minutes allocated to some physical education programs has decreased at the elementary level from an average of 90 minutes weekly in 3 class sessions to once per week for 20 minutes. Further, in the rapidly growing urban school district of 140,000 students in which we are evaluating the Be Active Kids! curriculum, none of the elementary schools built in the last 10 years has included a gymnasium. To magnify this problem, these schools host extensive feeding programs for children who qualify for free and reduced breakfast and lunch assistance, meaning that the multi-purpose rooms, which also serve as cafeteria, are unavailable for physical education during most of the school day. This means that during inclement weather, literally thousands of young children spend their physical education instructional time sitting quietly in their home rooms or performing jumping jacks behind their desks. Ever tightening budgets and reallocation of staff and training resources to literacy and mathematics means that physical educators receive minimal staff development updates on new techniques and technology and increasingly serve larger and multiple classes of students. Not only are they not held accountable for quality physical education programs, they are often ignored entirely.

I have always believed that respect must be earned. I have been hopeful over the last $25+$ years that by developing quality programs taught by skilled physical educators, physical education might earn a place of value in school programs. But we have countless examples of excellent physical educators who run quality programs who must fight every day to maintain control over facilities and instructional time and compete for miniscule amounts of resources. I don't believe the respect argument works very well in these contexts. In the face of increasing academic standards and comprehensive testing within an environment of limited and diminishing resources, will physical education content ever compete successfully with traditional academic subjects?

Clearly, this is a question of relative value. Although few school administrators or teachers would question the importance of physical activity for health and well-being, when pressed, however, most would respond that teaching literacy and mathematics is the school's primary mission. While most would agree that physical activity and physical education is greatly needed, the relative value of physical activity compared with the unquestioned value of literacy and mathematics relegates physical education to a low status, low demand subject. Can respect for a low demand subject, such as physical education, ever be earned in an academic environment?

Models of education "of and through the physical" such as those provided by The New Physical Education and the current generations of programs, such as lifetime fitness and physical activity (Corbin \& Lindsey, 2005), social 
responsibility (Hellison et al., 2000), sport education (Siedentop et al., 2004), and tactical approaches for teaching games (e.g., Mitchell et al., 2005) appear to reflect the educational philosophy espoused in schools. Our current NIH funded project, Be Active Kids! Science-based Physical Education, was designed to teach health-related science, reading, and mathematics concepts based on the National Education Standards in these areas and integrated deeply with cognitive concepts and physical performances included in the NASPE Physical Education Standards (NASPE, 2004). The student population in the 30 urban schools currently participating in our trial is over $80 \%$ minority - just the population we most need to reach. Information surrounding obesity and related health issues suggests that these students greatly need a regular, quality physical education curriculum taught by certified professional physical educators.

The school administrators with whom we work in the Be Active Kids! project are delighted with the idea that physical education can contribute to the academic mission of the school - but physical education in two of our successful experimental schools reported instructional time cuts this fall similar to those I discussed above. In this school district alone, physical education could reach over 140,000 students at very high risk to become overweight or obese. A quality physical education program is greatly needed but appears not to be valued relative to literacy and mathematics and is unable to compete successfully for resources (e.g., staff, instructional time, appropriate facilities, functioning equipment) in this urban school district.

In this academically intense environment, it would seem that physical education curricula focused more narrowly on public health or the "education of the physical" models would have an even greater challenge gaining a permanent foothold in schools once the funding agency no longer provides generous financial incentives to schools and school districts. Even highly successful programs such as SPARK and CATCH (e.g., McKenzie et al., 2001; Sallis et al., 1997) may soon face an uphill challenge in an era of No Child Left Behind (Department of Education, 2001) priorities. Although administrators and parents are concerned about child obesity, they are far more concerned about the immediate threat of reduced funding associated with static or declining test scores in reading and mathematics. It is clear that since the Sputnik era in the 1950s and 1960s, even academically oriented physical education programs of high quality have not been highly valued within academic school environments. Certainly the need is high, but demand supported by adequate resources is severely limited, short lived, or simply cannot be found. I am pleased to note that the National Institutes of Health, the Centers for Disease Control and Prevention (CDC) and Dr. Kenneth Cooper in his keynote speech to this Academy are very interested in promoting school-based physical education. The more difficulty question, however, is this: Are schools interested and willing to support quality physical education?

It does not appear that physical education is a very good fit within educational programs in the current political, economic, and educational environment. I have been a strong and consistent advocate for physical education programs in schools and have spent my professional career working to enhance and promote these programs. Although we still have much to learn, we currently have some very good ideas about effective curricula, teaching, and teacher education, but most innovative approaches to instruction and curriculum require qualified teachers, sufficient instructional time, and a commitment to build and maintain facilities to 
permit physical activity during hot/cold and rainy/snowy/dusty weather. Unfortunately, physical education has become a low demand subject relative to the schools' academic priorities.

\section{But What If . . . ?}

What if . . instead of locating physical education programs in schools, it were moved to community centers where it might be highly valued as the central, valued focus of the community rather than a peripheral appendage in schools. The CDC-funded Trial of Activity for Adolescent Girls (TAAG) program currently is examining some of the challenges of community-based physical activity/education. What if, in this scenario, physical educators would retain certain benefits won in labor agreements, preserving licensure requirements, salary and benefits, and fostering/ funding professional growth? As a program in high demand, community based physical education would receive priority in hiring, scheduling, and funding. Perhaps teachers would be located in community physical activity centers where they would not be required to spend valuable planning and reflection time teaching reading, monitoring bus duty, or providing planning periods for teachers in the valued tested subjects.

In community-based physical education programs, children from poor families would receive access to these programs through an open-door policy or perhaps through a system of physical activity stamps, like food stamps, that could be used to purchase physical activity time or instructionally based lessons in a host of traditional, cultural, and innovative physical activity and concept-based programs. Certainly, aspects of this model are being examined currently by teachers and physical activity entrepreneurs (Glod, 2005). This scenario would place a highly needed service in a high demand environment. It would provide access to populations most in need while avoiding the necessity of competing for resources with literacy and mathematics curricula in an academic environment.

Currently, school district physical educators are using PEP grant funding to connect and coordinate with those in the community who administer resources that can be used to provide physical activity opportunities. For example, one school district has partnered with their parks and recreation department to provide "Physical Education in the Park." Through this program, students have gained safe walking and jogging environments, climbing walls, in-line skating, skateboard, and "X-Games" classes, and opportunities to play on safe, well-maintained fields and facilities that are only a short walk away. In our Be Active Kids! Science-based Physical Education program, we invite families to a "Family Science Activity Night" in which the children lead family members through uncomplicated physical and nutritional experiments, while pointing out scientific principles that explain physiological changes and benefits resulting from regular moderate to vigorous exercise. These evening activities have been so successful they have overwhelmed our expectations and our initial ability to accommodate large numbers of enthusiastic families at these events.

It $i$ clear that education of and through the physical programs that promote the education of both mind and body should be housed and supported in places that are accessible to both children and families. Community-based physical education needs to be provided at no charge or through voucher systems so that low 
income families can participate in excellent facilities that accommodate family and work schedules. As the Centers for Disease Control and Prevention and Schools of Public Health focus attention on the role of the built environment in nurturing and promoting physical activity within our communities, a facility that includes an on-demand educational physical education program taught by certified, licensed, and well-paid physical educators should be a central and highly valued aspect of that design. These facilities and opportunities for continuing education of and through the physical are essential components of health and well-being. Perhaps these venues have yet to be created, but I think it's time we imagine, design, and build places where education of and through the physical holds a central role in American society accessible to all children and their families in a high need, high demand environment.

\section{References}

Azzarito, L., \& Solmon, M.A. (2005). A reconceptualization of physical education: The intersection of gender/race/social class. Sport Education and Society, 10(1), 25-47.

Bair, D.E. (1957). Identification of some philosophical beliefs of influential leaders in American physical education. The Research Quarterly, 28, 315-320.

Beauchamp, G. (1975). Curriculum theory (3rd ed.). Wilmette, IL: Kagg Press.

Broudy, H.S. (1982). What knowledge is of most worth? Educational Leadership, 39, 574-578.

Brown, C., \& Cassidy, R. (1963). Theory in physical education: A guide to program change. Philadelphia: Lea \& Febiger.

Capel, S., \& Piotrowski, S. (2000). Issues in physical education. London: Routledge/ Falmer.

Cassidy, R. (1954). Curriculum development in physical education. New York: Harper \& Brothers.

Cassidy, R., \& Kozman, H.C. (1943). Physical fitness for girls. New York: A.S. Barnes \& Co.

Corbin, C.B., Dowell, L.J., Lindsey, R., \& Tolson, H. (1970). Concepts in physical education: With laboratories and experiments. Dubuque, IA: Wm. C. Brown.

Corbin, C.B., \& Lindsey, R. (2005). Fitness for life (5th ed.). Champaign, IL: Human Kinetics.

Cowell, C.C., \& Hazelton, H.W. (1955). Curriculum designs in physical education. Englewood Cliffs, NJ: Prentice-Hall.

Department of Education (2001). No Child Left Behind Act of 2001. PL 107-110. Retrieved September 20, 2005, from http://www.ed.gov/policy/elsec/leg/esea02/ beginning.html\#sec3

Dewey, J. (1899). School and society. Chicago: University of Chicago Press.

Dewey, J. (1908). The child and the curriculum. Chicago: University of Chicago Press.

Dewey, J. (1913). Issues and effort in education. Boston: Houghton Mifflin.

Dewey, J. (1916). Democracy and education. New York: Macmillan.

Ennis, C.D., Chen, A., \& Sun, H. (2005). Curriculum fidelity: Teacher implementation of the externally designed Be Active Kids! curriculum. Paper presented at the annual meeting of the American Educational Research Association, Montreal.

Fraleigh, W.P. (1979). A philosophic basis for curriculum content in physical education for the 1980's. The Academy Papers, 13, 20-26.

Franks, B.D., \& Moore, G.C. (1969). Effects of calisthenics and volleyball on the AAHPER fitness test and volleyball skills. The Research Quarterly, 40, 288-292. 
Glod, M. (2005, October, 17). A hop, sprint, and jump beyond PE: Kids' after-school exercise clubs seek to fight obesity. The Washington Post, A1, 5.

Graham, G., Holt/Hale, S., \& Parker, M. (2004). Children's moving. Mountain View, CA: Mayfield.

Gulick, L.H. (1920). The philosophy of play. New York: Scribners.

Hall, G.S. (1920). Adolescence. New York: Appleton.

Halsey, E. (1964). Inquiry and invention in physical education. Philadelphia: Lea \& Febiger.

Hanmer, L.F. (1918). The Gary public schools: Physical training and play. New York: General Education Board.

Harris, D.V. (1981). Physical education: A house divided. The Academy Papers, 15, 3235 .

Hellison, D.R., Cutforth, N.J., Kallusky, J.P., Martinek, T.J., Parker, M.A., \& Stiehl, J. (2000). Youth development and physical activity. Champaign, IL: Human Kinetics.

Henry, F.M. (1964, January). Physical education: An academic discipline. Proceedings of the 67th annual conference of NCPEAM, pp. 6-9. [Reprinted in the Journal of Health, Physical Education and Recreation, 1964, 35, 32-33; 69].

Hetherington, C.W. (1922). School program and physical education. Yonkers, NY: World Book Co.

Hoepner, B.J. (1970). John Swett's experience with physical exercise at the Rincon School: Foundation for the first state physical education law in the U.S. The Research Quarterly, 41, 365-370.

Jewett, A.E. (1968). Implications from curriculum theory for physical education. The Academy Papers, 2, 10-18.

Jewett, A.E. (1973). Meaning and function of curriculum models: Comments relative to consideration of the "National Models." The Academy Papers, 7, 33-34.

Jewett, A.E. (1974). A new focus? The Academy Papers, 8, 2-8.

Jewett, A.E., \& Mullan, M.M. (1977). Curriculum design: Purposes and processes in physical education teaching-learning. Washington, DC: AAHPER.

Kennedy, J.F. (1960, Dec. 26). Soft American. Sports Illustrated, 14-17.

Kirk, D. (1988). Physical education and curriculum study: A critical introduction. New York: Croom Helm.

Kirkpatrick, W.H. (1922). The project method. New York: Teachers College, Columbia University.

Kraus, H., \& Hirschland, R.P. (1954). Minimum muscular fitness test in school children. Research Quarterly, 25, 177-188.

LaPorte, W.R. (1931). A study of relative values of thirty important activities in the physical education program for boys. The Research Quarterly, II, 115-141.

LaPorte, W.R. (1932). Report of the committee on curriculum research. The Research Quarterly, III, 130-141.

Lee, A., \& Solmon, M. (2005). Pedagogy research through the years in RQES. Research Quarterly for Exercise and Sport, 76, S108 - S121.

Lee, M. (1937).The conduct of physical education: It's organization and administration for girls and women. New York: A.S. Barnes.

Leonard, F.E. (1927). A guide to the history of physical education (2nd ed.). Edited and revised by R. Tait McKenzie. Philadelphia: Lea \& Febiger.

Lindeman, E.C. (1943). Preface. In R. Cassidy \& H.C. Kozman (Eds.), Physical fitness for girls (pp. v-vii). New York: A.S. Barnes \& Co.

Logsdon, B.J., Barrett, K.R., Ammons, M., Broer, M. R., Halverson, L.E., \& McGee, R. (1967). Physical education for children: A focus on the teaching process. Philadelphia: Lea \& Febiger. 
Maryland State Department of Education. (2004). Response to the No Child Left Behind Act of 2001. Baltimore: Author.

Mauldon, E., \& Redfern, H.B. (1969). Games teaching: A new approach for the primary school. London: MacDonald \& Evans.

Mechikoff, R.A., \& Estes, S.G. (1998). A history and philosophy of sport and physical education: From ancient civilizations to the modern world. Boston: McGraw-Hill.

McKenzie, R.T. (1923). Exercise in education and medicine. Philadelphia: Saunders.

McKenzie, T.L., Stone, E.J., Feldman, H.A., Epping, J.N., Yang, M., Strikmiller, P.K. Lytle, L.A., \& Parcel, G.S. (2001). Effects of the CATCH physical education intervention: Teacher type and lesson location. American Journal of Preventive Medicine, 21, 101109.

Mitchell, S.A., Oslin, J.L., \& Griffin, L.L. (2005). Teaching sport concepts and skills: A tactical games approach (2nd ed.). Champaign, IL: Human Kinetics.

Nash, J.B. (Ed.). (1931). Interpretation of physical education: Mind body relationships, Vol. 1. New York: A.S. Barnes \& Co.

National Association for Sport and Physical Education. (2003). National standards for beginning physical education teachers (2nd ed.). Reston, VA: AAHPERD.

National Association for Sport and Physical Education. (2004). Moving into the future: National Standards for Physical Education (2nd ed.). Reston, VA: AAHPERD.

Nixon, J.E. (1969). Needed curriculum reform. The Academy Papers, 3, 55-62.

Oberteuffer, D. (1951). Physical education: A textbook of principles for professional students. New York: Harper \& Brothers.

Penney, D., \& Evans, J. (1999). Politics, policy, and practice in physical education. New York: E \& FH Spon (Routledge).

Rosenstein, I., \& Frost, R.B. (1964). Physical fitness of senior high school boys and girls participating in selected physical education programs in New York state. The Research Quarterly, 35, 403-407.

Sage, G. (2003). Foreward. In A. Laker (Ed.), The future of physical education. Routledge: New York.

Sallis, J.F., McKenzie, T.L., Alcaraz, J.E., Kolody, B., Faucette, N., \& Howell, M.F. (1997). The effects of a 2-year physical education program (SPARK) on physical activity and fitness in elementary school students. American Journal of Public Health, 87, 13281334.

Saunders, R.J., Montoye, H.J., Cunningham, D.A., \& Kozar, A.J. (1969). Physical fitness of high school students and participation in physical education. The Research Quarterly, 40, 552-560.

Shulman, L.S. (1986). Those who understand: Knowledge growth in teaching. Educational Researcher, 15(2), 4-14.

Siedentop, D., Hastie, P., \& van der Mars, H. (2004). Complete guide to sport education. Champaign, IL: Human Kinetics.

Skarstrom, W. (1921). Gymnastics teaching. Springfield, MA: American Physical Education Association.

Spears, E., \& Swanson, R. (1978). History of sport and physical activity in the United States. Dubuque, IA: Wm. C. Brown.

Thorndike, E.L. (1913). Educational psychology. New York: Teachers College, Columbia University.

Ulrich, C., \& Nixon, J.E. (1972). Tones of theory: A theoretical structure for physical education -A tentative perspective. Washington, DC: AAHPER.

Vertinsky, P. (1991). Science, social science, and the "Hunger for Wonders" in physical education: Moving toward a future healthy society. The American Academy of Physical Education Papers, 24, 70-88. 
Wesley, W.A. (1970). Reaction to: Understandings about man moving. The Academy Papers, 4, 16-20.

Weston, A. (1962). The making of American physical education. New York: Appleton Century Crofts.

Williams, J.F. (1922). The organization and administration of physical education. New York: Macmillan.

Williams, J.F. (1930, May). Education through the physical. Journal of Higher Education, 1, 279-282.

Wood, T.D. (1924). The child in school (National Health Series). New York: Funk and Wagnalls.

Wood, T.D., \& Cassidy, R.F. (1927). The new physical education. New York: Macmillan. Zeigler, E.F. (1979). Past, present, and future development of physical education and sport. The Academy Papers, 13, 9-19.

US News and World Report (1954, March 19). Are U.S. kids falling behind? XXXVI(12), 35-36. 